\title{
臨床分離菌の常用消䇛剂に対する感受性*1
}

\author{
白石 正, 仲川義人*2, 北目文郎*3 \\ 山形大学医学部附属病院薬剤部*2 \\ 山形大学医学部細菌学教室*3
}

\section{Susceptibility of Clinical Isolates to Habitual Disinfectants*1}

\author{
TADASHI Shiraishi, Yoshito NAKAGAWA*2, and Fumio KITAME*3 \\ Department of Pharmacy, Yamagata University Hospital*2 \\ Department of Bacteriology, Yamagata University School of Medicine*3
}

(Received December 21, 1987)

\begin{abstract}
Susceptibility of 353 bacterial strains, composed of 6 genera and 9 species, which were isolated recently from various clinical materials in Yamagata University Hospital, to 4 disinfectants, chlorhexidine gluconate (CHG), benzalkonium chloride (BAC), saponated cresol (SAC), and povidone iodine (PVP-I), was examined.

1. All of the clinical isolates tested were sensitive to SAC and PVP-I, however, susceptibility of the isolates to $\mathrm{CHG}$ and BAC varied from species to species and also from strain to strain. 2. Most of the strains Serratia marcescens, Pseudomonas cepacia, Proteus mirabilis and Pr. vulgaris seemed to be insensitive to $\mathrm{CHG}$, though they were sensitive to $\mathrm{BAC}$. 3 . Many strains of Ps. cepacia were resistant to not only $\mathrm{CHG}$, but also BAC. 4. Most of the strains of Staphylococcus aureus, Sta. epidermidis, Escherichia coli, Klebsiella pneumoniae, and Ps. aeruginosa were estimated to be sensitive to CHG and BAC.

These results indicate that the resistant strains against $\mathrm{CHG}$ and $\mathrm{BAC}$ at the concentration recommended for disinfection of are be existent in some species of gram-negative bacteria of clinical isolates.
\end{abstract}

Keywords_-clinical bacterial isolate; gram-positive bacteria; gram-negative bacteria; susceptibility to; disinfectant; benzalkonium chloride; chlorhexidine gluconate; saponated cresol; povidone iodine

\section{緒謇}

病院内に常在している細菌や患者材料から日常分離さ れる細菌が, 通常の医療行為を通して, 易感染性宿主 (Compromised host) へ感染し, 発症したと考えられる 院内感染症が少なからず報告され1), 從来より医療従事 者にとって大きな問題となっている.このような感染症 は, 院内に持ける隇菌と消毒を適切に行うことによっ て，かなり減少するものと考えられる．乙かし，すべて の微生物に対して, その効果が絶対的なるのである隇菌

*1 本報の一部は第40回日本細菌学会東北支部会（青 森, 1986) 亿て発表.

*2,3 山形市蔵王飯田字西の前; Nishinomae, Zao Iida, Yamagata-shi, 990-23 Japan
とは異なり，消毒の場合は，その効果をあげるためにい くつかの困難な問題を解決しなければならない。すなわ ち, その施設内の常在菌ならびに臨床材料から日常分離 される細菌の種類とそれらの細菌の常用消毒剤に対する 感受性を明らかにし，その施設毎に最も適した消毒剤の 選択と適切な使用基準を定めるとともに，その効果が十 分に発揮されているか否かを常に把握していくことが必 要である.

臨床分離菌の種々の消毒剂に対する感受性を調べた成 績はこれまで多数報告されているが，試験法がそれぞれ の報告で異なっていることもあり，それらの成績が必ず しも一致していない，しかしながら，一般的には，グル コン酸クロルヘキシジン液 (CHG) に抵抗性を示す細菌 の分離頻度が，とりわけグラム陰性菌で高いといわれて 
おり,クレゾール石けん液やヨード製剤に対しては CHG 抵抗菌を含む多くの菌種が感受性を示すといわれてい る $^{2 \sim 15)}$.

一方，種々の細菌において，CHG に対する感受性は分 離株と標準株の間で差がないという報告もある7が，わ れわれの行った予備実験では分離菌と標準菌との間に消 毒剂に対する感受珄に大きな差のあるものが見いだされ ている(16). したがって, 当該施設に执ける臨床分離菌の 消毒剤に対する感受性を個々の施設毎に調査し, その施 設に最も適した消毒剤の使用に関する指針を確立するこ とが極めて重要であると考える.

本研究は, 上述した観点に基づき, 山形大学医学部付 属病院に扣いて患者材料から日常分離されている細菌の 常用消毒剂に対する感受性を明らかにし，常用消毒剂の 有効性について検討したものである.

\section{実 臨 の 部}

\section{1. 実殹材料}

1)使用細菌 臨床分離菌: 山形大学医学部付属病院中 央検查部において, 昭和60年 8 月から昭和 61 年 7 月まで の 1 年間に種々の患者材料から分離された 6 属 9 種の合 計 353 株を被験菌とした（Table 1).

Table 1 から明らかなように, 細囷分離に用いた患者 材料及びその由来は多岐にわたって拈り, 特定の診療科 や材料に片寄ったものではない.
標準菌：対照として以下の 6 属 9 種, 合計13株の標準 菌を使用した。

Staphylococcus aureus FDA 209-P, St. epidermidis ATCC 12229, Escherichia coli NIHJ JC-2, Klebsiella pneumoniae IFO 12009, Serratia marcescens IFO 3064, Pseudomonas aeruginosa IFO 3455, Ps. cepacia M-0257, Proteus mirabilis IFO 3849, 及び Pr. vulgaris IFO 3988.

2)使用薬郕：グルコン酸クロルヘキシジン液 (CHG) :(ヒビテン液®， $5 \%(\mathrm{w} / \mathrm{v})$, ICI ファーマLot No. pt 274 ), 塩化ベンザルコニウム液 $(\mathrm{BAC})$ : (日局品, 山田製薬, Lot No. 50473), クレゾール石ケン液 (SA C) : (日局品, 岩城製薬, Lot No. 50130) 及びポビド ンョード液 $(\mathrm{PVP}-\mathrm{I})$ : (イソジン液 ${ }^{\circledR}, 10 \%(\mathrm{w} / \mathrm{v})$, 明治製菓, Lot No. ADL521). 各消毒剤は用時減菌蒸 留水で希釈して使用した。

\section{2. 実験方法}

試験菌液の調整：分離菌及び標準菌を普通ブイョン 〔乾燥ブイヨン(ニッスイ)〕で $37^{\circ} \mathrm{C}, 24$ 時間静置培埕 乙た培養液を最小発育阻止濃度 (MIC) 測定用の菌液と した。また，本培養液から遠心沈殿法によって得た細菌 細胞を隇菌生理食塩液で洗浄後, 同食塩液で $10^{8} \mathrm{CFU} /$ $\mathrm{ml}$ に調整した菌液を最小殺菌濃度（MBC）測定用に用 いた.

MIC の測定 : 寒天培地希釈法によって種々の濃度の

Table 1. Distribution of Clinical Isolates in Clinical Divisions and Materials

\begin{tabular}{|c|c|c|c|c|c|c|c|c|c|c|c|c|c|c|c|c|c|}
\hline \multirow{3}{*}{ clinical isolates tested } & \multirow{3}{*}{$\begin{array}{l}\text { No.of } \\
\text { strains } \\
\text { tested }\end{array}$} & \multicolumn{16}{|c|}{ distribution of isolates in } \\
\hline & & \multicolumn{9}{|c|}{ clinical divisions 2 ) } & \multicolumn{7}{|c|}{ clinical materials ${ }^{a)}$} \\
\hline & & A & B & c & $D$ & $\mathrm{E}$ & $\mathbf{F}$ & G & $\mathrm{x}$ & $\mathbf{H}$ & $I$ & $\mathrm{~J}$ & K & I & M & $\mathrm{N}$ & $x$ \\
\hline Staphylococcus aureus & 76 & 20 & 29 & 9 & 1 & 1 & 9 & 1 & 6 & 6 & 15 & 27 & & 10 & 1 & 7 & 10 \\
\hline Staphylococcus epidermidis & 20 & 8 & 3 & & 1 & 3 & 2 & & 3 & 3 & 5 & & & 1 & 2 & 4 & 5 \\
\hline Escherichia coli & 54 & 20 & 9 & 8 & 5 & 3 & 1 & 1 & 7 & 27 & 9 & 4 & 3 & & 3 & & 8 \\
\hline Klebsiella pneumoniae & 53 & 30 & 4 & 2 & 1 & 3 & 1 & 1 & 11 & 13 & 5 & 20 & & 1 & 1 & 7 & 6 \\
\hline Serratia marcescens & 47 & 15 & 9 & & & 10 & 1 & 5 & 7 & 30 & 3 & 6 & & & 2 & & 6 \\
\hline Pseudomonas aeruginosa & 51 & 19 & 16 & 1 & & 4 & 1 & 2 & 8 & 8 & 9 & 27 & & 1 & & 3 & 3 \\
\hline Pseudomonas cepacia & 17 & 9 & 4 & & & & & & 4 & 2 & 2 & 6 & 1 & & 3 & & 3 \\
\hline Proteus mirabilis & 19 & 3 & 5 & & 2 & 2 & 4 & & 3 & 8 & 1 & 3 & 1 & 3 & & & 3 \\
\hline Proteus vulgaris & 16 & 2 & 6 & & & 1 & & 1 & 6 & 6 & 4 & & & & & & 6 \\
\hline
\end{tabular}

Total number of isolates tested are 353 strains.

a) The clinical divisions and materials are alphabetized : $A$; Internal medicine, B; Surgery, C; Pediatrics, D; Obstetrics and Gynecology, E; Urology, F; Otolaryngology, G; Dermatology, H; Urine, I; Pus, J; Sputum, K; Feces, I; Otorrher, M; Brood,"N; Swab, and $X ;$ Others 
$\mathrm{CHG}, \mathrm{BAC}$ 及び SAC 液を含む培地を作成し，種々の 菌株に対する MIC を求めた. すなわち, 上記 3 種の消 毒剤をそれぞれ種々の濃度で含有する普通寒天平板を検 定培地として, 各被験菌の 1 白金耳を接種し, $37^{\circ} \mathrm{C} て ゙ 24$ 時間培養後, 菌の增殖を完全に抑えた消毒剤の最小濃度 をその菌に対する MIC とした。

$\mathrm{MBC}$ の測定：液体希釈法によって PVP-I の種々の 菌株に対する $\mathrm{MBC}$ を求めた。すなわち, 種々の濃度の PVP-I を含む隇菌蒸留水 $5 \mathrm{ml}$ に上述した被験菌の 0.1 $\mathrm{ml}$ を加光, $20^{\circ} \mathrm{C}$ で 1 分間放置後, それぞれの 1 白金耳 を $0.0025 \%$ のチオ硫酸 $\mathrm{Na}$ 液を含む普通寒天平板に接 種し， $37^{\circ} \mathrm{C}$ で24時間培養後の細菌増殖の有無により， 完全に被験菌を殺菌した最小濃度を MBC とした。な お，用いた $0.0025 \%$ チ才硫酸 $\mathrm{Na}$ 液は被験菌の增殖を 妨げずにヨウ素の殺菌活性を完全に中和することを確認 し用いた。

\section{結果}

\section{1. 山形大学医学部付属病院における繁用消毒郕の使}

\section{用状況}

昭和60年 4 月 1 日から同年 11 月 8 日までの約 7 カ月間 に, 当病院で使用された主な手指用消毒剤の種類, 常用 濃度及びその使用量を常用濃度飞換算し, Table 2 亿示 した.ビグアニド系の消毒剤として，ヒビテン液，ヒビ テングルコネート液, 及びヒビスクラブの 3 製剤が使わ れており，その合計 151200 が全体の消毒剂使用量の $53.4 \%$ 占めていた。次に使用量が多かったのは PVP-I
と $\mathrm{BAC}$ であり， $\mathrm{SAC}$ の使用量は全体の $3.8 \%$ とすぎ なかった。

\section{2. 各喠臨床分離菌の消毒剈に対する感受性}

3 種の消毒剤, CHG，BAC 及び SAC に対する感受 性は一般に行われている MIC 法で, PVP-I 飞対する感 受性についてはヨウ素の培地による影響を考慮し MBC 法で求め, その結果を消毒剤毎にまとめ, Table $3 \mathrm{~A}-\mathrm{D}$ に示した。 また，分離株に対する MIC あるいは MBC 值が標準株に対する MIC あるいは MBC 值の10倍また はとれ以上の高値を示した菌の分離頻度を Table 4 亿示 した.

\section{（1） CHG に対する感受性}

分離菌の本消毒剂に対する感受性は，菌種及び菌株に よってさまざまであった. St. aureus 及び Pr. mirabilisでは，分離株のほぼ90\%以上がそれぞれの菌種毎に 同一の MIC 值を示し，分離株每による感受性の大きな 違いは認められなかった。これに対して，分離株毎に感 受性の異なる菌種も認められ, 分離株間の MIC 值に $K$. pneumoniae では1000倍, E. coli 及び Se. marcescen では 100 倍及び Pseudomonas 属の 2 菌種ではそれぞれ 25倍ないしそれ以上の開きが観察された（Table 3-A). また，標準株と同じかまたはそれより低い MIC 值を示 す株，すなわち CHGに対して感受性株とみなし得るむ のの分離頻度が50\%以上であった菌種は, St.aureus (76 株中70株), E. coli (54株中31株), K.pneumoniae (53 株中51株), Ps. aeruginosa (51株中50株), Pr. mirabilis (19株中19株), 及び Pr. vulgaris (16株中 9 株)

Table 2. The Amount of Disinfectants Consumed in Yamagata University Hospital from January to August 1985

\begin{tabular}{|c|c|c|c|}
\hline Disinfectants & $\begin{array}{l}\text { Habitual } \\
\text { concentration } \\
\qquad(8)\end{array}$ & $\begin{array}{l}\text { Amount of } \\
\text { consumption a) } \\
\begin{array}{ll}(x 102 & 1)\end{array}\end{array}$ & $\begin{array}{l}\& \text { of total } \\
\text { amount }\end{array}$ \\
\hline Hibitain solution ( $\mathrm{CHG}$ ) & 0.1 & 1183 & 41.7 \\
\hline $\begin{array}{c}\text { Hibitain gluconate } \\
\text { solution }\end{array}$ & 0.05 & 325 & 11.5 \\
\hline Hibisclube & 4.0 & 4 & 0.2 \\
\hline Isodin solution (PVP-I) & 0.1 & 689 & 24.8 \\
\hline $\begin{array}{r}\text { Benzalkonium chloride } \\
\text { solution(BAC) }\end{array}$ & 0.1 & 510 & 18.0 \\
\hline $\begin{array}{l}\text { Saponated cresol } \\
\quad \text { solution (SAC) }\end{array}$ & 2.0 & 106 & 3.8 \\
\hline
\end{tabular}

a) Amount of disinfectants used at habitual concentration 
Table 3-A. Susceptibility of Clinical Isolates and Standard Strains to Chlorhexidine Gluconate ( $\mathrm{CHG}$ )

\begin{tabular}{|c|c|c|c|c|c|c|c|}
\hline \multirow{2}{*}{ strains } & \multirow{2}{*}{$\begin{array}{l}\text { No.of } \\
\text { strains } \\
\text { tested }\end{array}$} & \multicolumn{4}{|c|}{ No.of strains with MIC } & \multicolumn{2}{|c|}{$(z, w / v)$ of } \\
\hline & & $>0.5$ & 0.5 & 0.2 & 0.02 & 0.002 & 0.0002 \\
\hline Staphylococcus aureus & 76 & & & & 6 & 70 & \\
\hline St.aureus FDA 209-P & 1 & & & & & 1 & \\
\hline St. epidermidis & 20 & & & & & 12 & 8 \\
\hline St.epidermidis ATCC 12229 & 1 & & & & & & 1 \\
\hline Escherichia coli & 54 & & & & 5 & 18 & 31 \\
\hline E. Coli NIHJ JC-2 & 1 & & & & & & 1 \\
\hline Klebsiella pneumoniae & 53 & & & 2 & 49 & & 2 \\
\hline K.pneumoniae IFO 12009 & 1 & & & & 1 & & . \\
\hline Serratia marcescens & 47 & & & 27 & 25 & 5 & \\
\hline Se.marcescens IFO 3064 & 1 & & & & & 1 & \\
\hline Pseudomonas aeruginosa & 51 & & 1 & 25 & 25 & & \\
\hline Ps.aeruginosa IFO 3455 & 1 & & & 1 & & & \\
\hline Ps. cepacia & 27 & 4 & 9 & 2 & 2 & & \\
\hline Ps.cepacia M-0257 & 1 & & & & 1 & & \\
\hline Proteus mirabilis & 19 & & & 27 & 2 & & \\
\hline Pr.mirabilis IFO 38491 & 1 & & & 1 & & & \\
\hline Pr.vulgaris & 16 & & & 7 & 9 & & \\
\hline Pr.vulgaris IFO 3988 & 1 & & & & 1 & & \\
\hline
\end{tabular}

であった.これらの菌種とは異なり，標準株の MIC 值 より10倍またはそれ以上の高い值を示し，CHG に抵抗 性を示すと予測される株の分離頻度は, Se. marcescens (47株中42株, 89\%), 及び Ps. cepacia（17株中15株, 88\%) で高かった. St. epidermidis の場合も抵抗性を示 すと考えられる株の分離頻度が高かった（20株中12株, 60\%) が，それらの株に対する MIC 值は $0.002 \%$ と， 非常に低い值であった. 感受性株が半数以上認められた E. coli と Pr. vulgaris であ，抵抗性とみなし得る株 がそれぞれ43\%と44\%を占めていた（Table 4).

\section{(2) BAC に対する感受性}

MIC 值が分離株間で大きく異なっている菌種は， $E$. coli, K. pneumoniae, Se. marcescens 及び Ps.aeruginosa で目立っていた (Table 3-B). 他の菌種では分 離株の大半がそれぞれほぼ同一の MIC 值を示し, 分離 株間で感受性が大きく異なる傾向は認められなかった。 BAC に対して抵抗性を示すと予測される株の分離頻度 はPs. cepacia で目立つ（17株中12株，70\%) だけで， Se. marcescens, Ps. aeruginosa 及び Ps. mirabilis
でそのような株が認められるものの，その分離頻度はせ いぜい10〜20\%程度であった. St. aureus の場合は，標 準菌に比較し感受性が劣っている株の分離頻度が $33 \%$ と 高かったが，それらの株に対する MIC 值は $0.0005 \%$ と 非常に低い值であった。他の菌種では，感受性株と考兄 られるものの分離頻度が，80\%を越えていた（Table 4).

\section{（3） SAC に対する感受性}

Ps. aeruginosa 及び Ps.cepacia を除く 5 属 7 種の分 離菌のほとんどすべては，それぞれの標準株と全く同じ か，またはそれより低い MIC 值を示した (Table 3-C). Ps. aeruginosa では51株中 33 株 (65\%), Ps. cepacia では17株中16株（94\%）に対する MIC 值がそれぞれの 標準株に対する MIC 值より10倍またはそれ以上高い値 を示したことにより，Pseudomonas 属の 2 種の多くの 分離株が SAC に抵抗性を示すことが予測された(Table 4). Pr. mirabilis での抵抗性株の分離数は19株中 1 株 にすぎなかった。 
Table 3-B. Susceptibility of Clinical Isolates and Standard Strains to Benzalkonium Chloride (BAC)

\begin{tabular}{|c|c|c|c|c|c|c|c|}
\hline \multirow{2}{*}{ strains } & \multirow{2}{*}{$\begin{array}{l}\text { No.of } \\
\text { strains } \\
\text { tested }\end{array}$} & \multicolumn{3}{|c|}{ No.of strains } & \multicolumn{3}{|c|}{ with $\operatorname{MIC}(z, w / v)$ of } \\
\hline & & 5 & 0.5 & 0.05 & 0.005 & 0.0005 & 0.00005 \\
\hline Staphylococcus aureus & 76 & & & & & 25 & 51 \\
\hline St.aureus FDA 209-P & 1 & & & & & & 1 \\
\hline St.epidermidis & 20 & & & & & 20 & \\
\hline St.epidermidis ATCC 12229 & 1 & & & & & 1 & \\
\hline Escherichia coli & 54 & & 1 & 41 & 12 & & · \\
\hline E. coli NIHJ JC-2 & 1 & & & 1 & & & \\
\hline Klebsiella pneumoniae & 53 & & & 18 & 33 & 2 & \\
\hline K.pneumoniae IFO 12009 & 1 & & & 1 & & & \\
\hline Serratia marcescens & 47 & 1 & 5 & 37 & 4 & & \\
\hline Se.marcescens IFO 3064 & 1 & & & 1 & & & \\
\hline Pseudomonas aeruginosa & 51 & 2 & 9 & 40 & & & \\
\hline Ps.aeruginosa IFO 3445 & 1 & & & 1 & & & \\
\hline Ps.cepacia & 17 & & 12 & 5 & & & \\
\hline Ps.cepacia M-0257 & 1 & & & $I$ & & & \\
\hline Proteus mirabilis & 19 & & 4 & 15 & & ' & \\
\hline Pr.mirabilis IFO 38491 & 1 & & & 1 & & & \\
\hline Pr.vulgaris & 16 & & & 16 & & & \\
\hline Pr.vulgaris IFO 3988 & 1 & & & 1 & & & \\
\hline
\end{tabular}

\section{(4) PVP-I に対する感受性}

本消毒剂の場合, 全分離株に対する $\mathrm{MBC}$ の值がいず れも標準菌と同じか, 高くてもせいぜい 5 倍の範囲内に 収まるものだけであった。すなわち，今回検討した臨床 分離株のすべてが本消毒剂に対して感受性を示するのと 考えられた（Table 3-D).

\section{2 剂以上の消毒剤に同時に抵抗性を示すと予測さ}

\section{れる分離株の存在}

2 種以上の消毒剤に同時に抵抗性を示すと予測される 分離株の存在も認められた. 寸なわち, ある分離株に対 する MIC あるいは MBC 值が標準株に比べ10倍または それ以上の高值を示した薬剤が同時に 2 種以上存在した 菌の有無を調べたところ，St. aureus では 76 株中 4 株 (5\%), E. coli では54株中 1 株 ( $2 \%)$, Se. marcescens では47株中 6 株 (13\%), Ps. aeruginosa では51 株中 1 株 ( $2 \%)$ が $\mathrm{CHG}$ と $\mathrm{BAC}$ の 2 剂に同時に抵抗 性を示すことが予測された，さらに，Ps．cepacia にお いては17株中12株 $(70 \%)$ の分離株が, CHG, BAC の 他に SAC を含む 3 剂に同時に抵抗性を示すと予測され
た。

4. Se. marcescens, Ps. aeruginosa, Ps. cepacia, Pr. mirabilis 及び Pr. vulgaris の MBC 法に

\section{よる感受性試験}

MIC 法による一次スクリーニングの結果, 各消毒剂 の常用濃度 〔(CHG，BAC，PVP-I；0.1\%(w/v) 及び $\mathrm{SAC} ; 2 \%(\mathrm{v} / \mathrm{v})]$ 並びにそれぞれの菌種の標準菌に対 する MIC または MBC 值を基準にして，分離株の感受 性を判断したところ，CHG，BAC 及び SAC に対する 感受性が低下している株の分離頻度が，グラム陰性菌の Se. marcescens 及び Pseudomonas 属とProteus 属の それぞれ 2 菌種で高いことが判明した (Table 4).

そこで, これらの 5 菌種の抵抗性株の中から，それぞ れ 3 株を任意に選び, さらに MBC 法による感受性試験 を行い，その結果を Table 5 に示した。すなわち， SAC に対しては調べた株のすべてが，それぞれの菌種の標準 株と同様, 常用濃度の SAC によって30秒以内に完全に 殺菌され，感受性を示すことが判明した。これに対して CHG と BAC に対する感受性は, 菌種並びに菌株毎に 
Table 3-C. Susceptibility of Clinical Isolates and Standard Strains to Saponated Cresol (SAC)

\begin{tabular}{|c|c|c|c|c|c|}
\hline \multirow{2}{*}{ strains } & \multirow{2}{*}{$\begin{array}{l}\text { No.of } \\
\text { strains } \\
\text { tested }\end{array}$} & \multicolumn{4}{|c|}{ No.of strains with MIC $(z, v / v)$ of } \\
\hline & & 2 & 1 & 0.1 & 0.01 \\
\hline Staphylococcus aureus & 76 & & & 74 & 2 \\
\hline St. aureus FDA 209-P & 1 & & & 1 & \\
\hline st.epidermidis & 20 & & & 20 & \\
\hline St.epidermidis ATCC 12229 & 1 & & & 1 & \\
\hline Escherichia coli & 54 & & & 54 & \\
\hline E.coli NIHJ JC-2 & 1 & & & 1 & \\
\hline Klebsiella pneumoniae & 53 & & & 53 & \\
\hline K.pneumoniae IFO 12009 & 1 & & & 1 & \\
\hline Serratia marcescens & 47 & & & 47 & \\
\hline Se.marcescens IFO 3064 & $I$ & & & 1 & \\
\hline Pseudomonas aeruginosa & 51 & 4 & 29 & 18 & \\
\hline Ps.aeruginosa IFO 3445 & 1 & & & 1 & \\
\hline Ps.cepacia & 17 & & & 16 & 1 \\
\hline Ps.cepacia $\quad M-0257$ & 1 & & & & 1 \\
\hline Proteus mirabilis & 19 & & 1 & 18 & \\
\hline Pr.mirabilis IFO 38491 & $I$ & & & 1 & \\
\hline Pr.vulgaris & 16 & & & 16 & \\
\hline Pr.vulgaris IFO 3988 & $I$ & & & 1 & \\
\hline
\end{tabular}

異なっていた. すなわち, BAC に対して, Ps. aeruginosa, Pr. mirabilis 及び Pr. vulgaris の全 9 株は, そ れぞれの標準株と同様，常用濃度の BACによって30秒 以内に殺菌され，感受性を示したが，Se. marcescens 及 び Ps. cepacia の分離株は，それぞれの標準株より感受 性が低下しており，30秒の接触ではいずれの株も殺菌さ れず，殺菌されるためには 3 分あるいはそれ以上の接触 時間を必要とした。

また，CHG に対してはPs. aeruginosaの 3 株だけが 感受性を示したが, Se. marcescens, Ps. cepacia, Pr. mirabilis 及び Pr. vulgaris の12株は，いずれも常用濃 度の CHG では短時間による接触で殺菌されず, 抵抗性 を示した. 特に, Ps. cepacia と Pr. mirabilis の場合 は標準株も抵抗性を示し, 本消毒剤はこの 2 菌種に対し ては，全く無効であることが判明した。

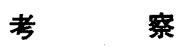

各種細菌に対する消毒剤の効果を調べる方法には，最 小殺菌濃度 (MBC) 法, 最小発育阻止濃度 (MIC) 法, 石
炭酸係数法及びそれらの変法等, 数多くあるが, 試験の 目的に応じてそれらの特徴を生かして使い分けることが 必要である17).

本研究では, 多数の臨床分離株に対する各種消毒剂の 感受性を調べ，消毒剤に抵抗性を示すと思われる株の分 離頻度の概略を把握することを目的として，一次スクリ ーニングを MIC 法で行い，そこで抵抗性を示した株に ついて MBC 法を用いて,さらに詳細に検討するという 方法を採用した。しかし，培地中の成分によって，その 殺菌力が低下するといわれている PVP-I18) に対する感 受性試験は，一次スクリーニングの段階で MBC 法を用 いた。 また，抵抗性の株か否かの判定は，それぞれの分 離株に対する消毒剤の MIC 值がその被験菌種の標準株 に対する MIC 值より，10倍かそれ以上の高値を示した 株を抵抗性株とする基準を設け，それに基ついて行っ た.上述した基準によれば, Table 4 に見られるよう に, St. aureus の25株 (33\%) が BAC に対して, St. epidermidis の12株 (60\%), E. coli の23株 (43\%) が CHG に対して, さらに Ps. cepacia の16株 (94\%) が 
Table 3-D. Susceptibility of Clinical Isolates and Standard Strains to Povidone Iodine (PVP-I)

\begin{tabular}{|c|c|c|c|c|c|}
\hline \multirow[b]{2}{*}{ strains } & \multirow{2}{*}{$\begin{array}{l}\text { No.of } \\
\text { strains } \\
\text { tested }\end{array}$} & \multicolumn{3}{|c|}{ No. of strains with $\operatorname{MBC}(z, w / v)$} & \multirow[t]{2}{*}{ of } \\
\hline & & 0.008 & 0.0016 & 0.00032 & \\
\hline Staphylococcus aureus & 76 & 4 & 72 & & \\
\hline St.aureus FDA 209-P & 1 & & 1 & & \\
\hline St.epidermidis & 20 & 1 & 18 & 1 & \\
\hline St.epidermidis ATCC 12229 & 1 & & 3 & & \\
\hline Escherichia coli & 54 & 12 & 40 & 2 & \\
\hline E.coli NIHJ JC-2 & 1 & & 1 & & \\
\hline Klebsiella pneumoniae & 53 & 20 & 31 & 2 & \\
\hline K.pneumoniae IFO 12009 & 1 & & 1 & & \\
\hline Serratia marcescens & 47 & 5 & $4 I$ & 1 & \\
\hline Se.marcescens IFO 3064 & 1 & & 1 & & \\
\hline Pseudomonas aeruginosa & 51 & 13 & 38 & & \\
\hline Ps.aeruginosa IFO 3445 & 2 & & 1 & & \\
\hline Ps.cepacia & 17 & 2 & 15 & & \\
\hline Ps. cepacia M-0257 & 1 & & 1 & & \\
\hline Proteus mirabilis & 19 & 2 & 14 & 3 & \\
\hline Pr.mirabilis IFO 38491 & 1 & & 1 & & \\
\hline Pr.vulgaris & 16 & & 12 & 4 & \\
\hline Pr.vulgaris IFO 3988 & 1 & & 1 & & \\
\hline
\end{tabular}

Table 4. Frequency of Isolation of Strains with 10-fold and More Higher MIC or MBC Comparing with That of Standard Strains

\begin{tabular}{|c|c|c|c|c|c|}
\hline \multirow{2}{*}{ strains } & \multirow{2}{*}{$\begin{array}{l}\text { No.of } \\
\text { strains } \\
\text { tested }\end{array}$} & \multicolumn{4}{|c|}{ Frequency $(z)$ for } \\
\hline & & $\mathrm{CHG}$ & BAC & SAC & PVP-I \\
\hline Staphylococcus auxeus & 76 & 8 & 33 & 0 & 0 \\
\hline St. epidermidis & 20 & 60 & 0 & 0 & 0 \\
\hline Escherichia coli & 54 & .43 & 2 & 0 & 0 \\
\hline Klebsiella pneumoniae & 53 & 4 & 0 & 0 & 0 \\
\hline Serratia marcescens & 47 & 89 & 13 & 0 & 0 \\
\hline Pseudomonas aeruginosa & 51 & 2 & 22 & 65 & 0 \\
\hline Ps.cepacia & 17 & 88 & 70 & 94 & 0 \\
\hline Proteus mirabilis & 19 & 0 & 21 & 5 & 0 \\
\hline Pr.vulgaris & 16 & 44 & 0 & 0 & 0 \\
\hline
\end{tabular}


Table 5. Susceptibility of Se. marcescens, Ps. aeruginosa, Ps. cepacia, Pr. mirabilis and Pr. vulgaris to $\mathrm{CHG}, \mathrm{BAC}$ and $\mathrm{SAC}$

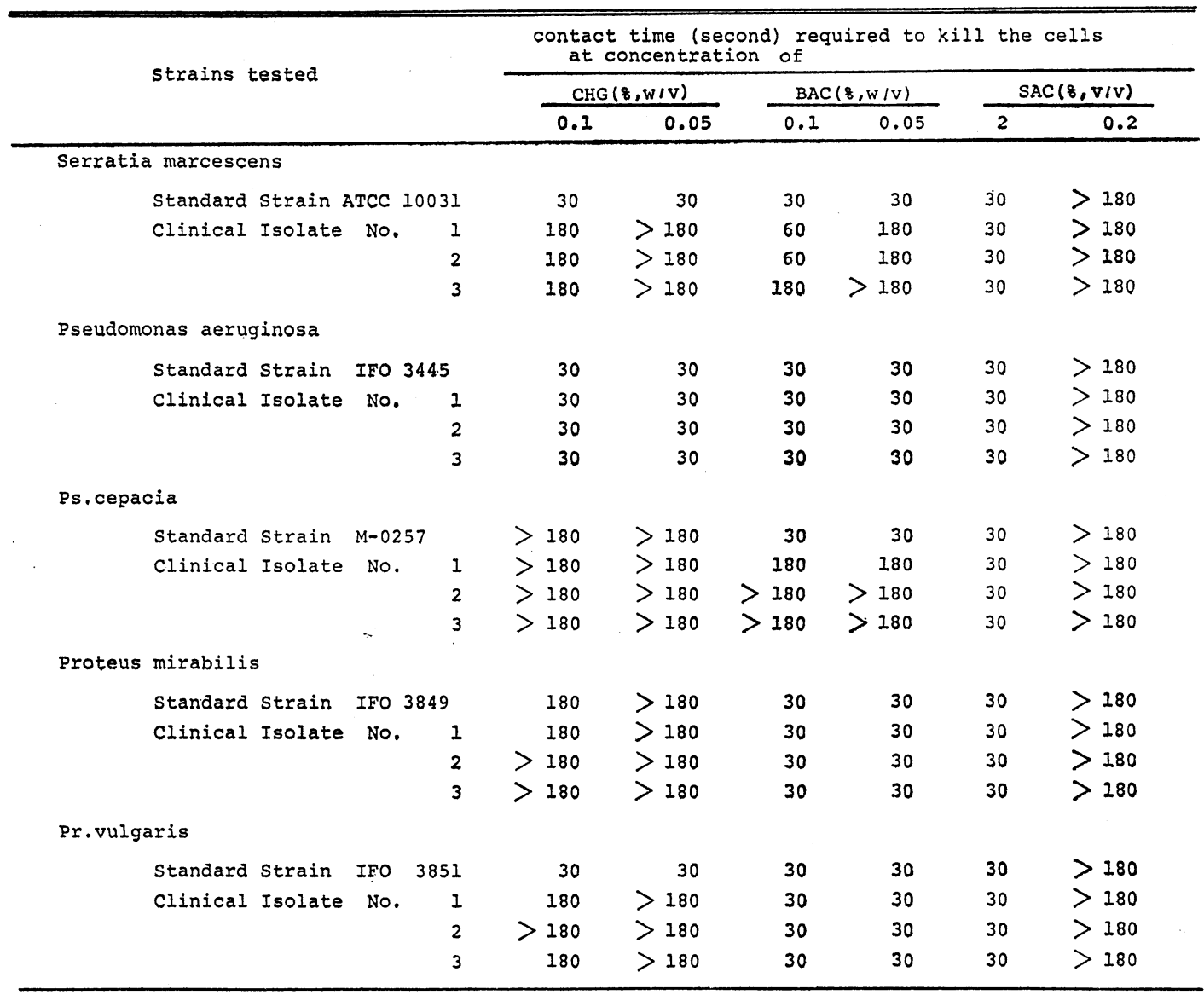

SAC に対して，それぞれ抵抗性の株としてみなすこと ができるが,いずれの場合もとれらの株に対する MIC 值 は，それぞれの消毒剤の常用濃度 (CHG；0.1\%, BAC; $0.1 \%$ ，及び SAC；2\%）よりかなり低值であり（Table 3-A, B, C), 実際の場では感受性菌として挙動するもの と考えられたので, これらの株については MBC 法によ る検討を行わなかった。

これに対して，標準株に対する MIC 值がそれぞれの 消毒剂の常用濃度に近く, 分離株に対する MIC 值との 閏に10倍以上の差が認められた例として， CHG に対す る Se. marcescens の42株 $(89 \%)$, Ps. cepacia の15株 $(88 \%), P r$. vulgaris の 7 株 $(44 \%)$, 及び BACに対 する Se. marcescens の 6 株 (13\%), Ps. aeruginosaの 11株 (22\%), Ps.cepacia の12株 (70\%), Pr.mirabilis の 4 株 $(21 \%)$ ，及び SAC に対するPs. aeruginosa の 33 株 $(65 \%)$ があり，いずれも抵抗性とみなされた。さ
らにそれぞれの菌種ごとに抵抗性株を任意に 3 株ずつ選 び, MBC 法による検討を試みた.

その結果, Table 5 に示したよらな成績が得られた。 すなわち， MIC 法では BAC と SAC に対して抵抗性 を示すとみなされたPs. aeruginosa の 3 株は， $\mathrm{MBC}$ 法 ではいずれの消毒剤に対しても感受性を示し，MIC法と $\mathrm{MBC}$ 法の成績が一致しない結果となった。その理由は 不明であるが，本菌種の消毒剤感受性試験は，実際の場 での使用条件に近い MBC 法で行うことがより良いと考 えられる. 一方，同じ Pseudomonas 属の cepacia の場 合は, MIC 法での予測が MBC 法によっても確認され， 同属であっても菌種によって感受性の陚験法に対する挙 動が必ずしも一致しないことが示された。

なお，Ps. cepacia 及び Pr. mirabilis は，CHG に対 してはそれらの標準株並びに用いた 3 株のすべてが非感 受性であり, 本 2 菌種に対して $\mathrm{CHG}$ は全く無効である 
ことが明らかになった. さらに, Ps. cepacia は, BAC に対しても 3 株中 2 株は全く感受性を示さず残りの 1 株 も, 常用濃度で殺菌されるためには長時間の接触を必要 とすることが示され, 本菌種のある株に対しては CHG と同様， BAC もほとんど効果が期待できないものと思 われた. また, Se. marcescens の場合す CHG と $\mathrm{BAC}$ に対して, 全く感受性を示さない株が存在し, CHG と $\mathrm{BAC}$ は本菌種の殺菌の目的には不適であると考えられ た.

さらに, 一次スクリーニングの結果, Proteus 属の 2 菌種の場合も BAC や CHG に抵抗性を示す株の存在が 予測されたので，MBC 法による確認を行った．両菌種 共に BAC に対してはそれぞれの標準株と同様の感受性 を示したが CHG に対しては抵抗性を示した.すなわ ち, Pr. mirabilis の場合は分離株のみならず標準株も 本剂に対して非感受性であり，Ps. cepacia とならんで Pr. mirabilis に対しても CHG は無効であることが判 明した. Pr. vulgaris の場合標準株は常用濃度で30秒以 内に完全に殺菌され, 感受性を示したが, 分離株は常用 濃度での殺菌に抵抗し, 本菌種を CHG を用いて除去す ることは困難であると思われた。

以上のように, Se. marcescens と Ps. cepacia の臨 床分離株の中には CHG に対して全く感受性を示さない 株が約 $90 \%$ の頻度で存在していること，及び10-20\%程 度の低い頻度ではあるものの, 両菌種の分離株の中に は, BAC に対しても抵抗性を示す株の存在が明らかと なった. CHG や BAC が Serratia 属, Pseudomonas 属及び Proteus 属の細菌に無効であるという報告はこれ までもなされており ${ }^{8 \sim 13)}$, 本研究の成績もそれらの成績 と一致するすのであった. Table 2 に示したように, 本 院に和ける CHG と BAC の使用量は, 全体の消毒剂の 使用量の70\%以上にも達して扣り, Serratia 属, Pseudomonas 属及び Proteus 属による院内感染の予防とい う観点からみれば, 本研究は現在の当院に拉ける消毒剤 の選択基準を見直す必要があることを示するのである.

富岡らは, 病棟内での Pseudomonas 属の検出率が, 本属に有効な Minomycin や Piperacillin 等の抗生物質 の使用によってよりは, 消毒剂 (PVP-I) の使用によっ て激減した事実から，院内環境での菌の分布が消毒剂に よって左右されることを立証している19). われわれる臨 床分離菌のみならず常在菌についても定期的な感受性試 験を行い，その時点で感受性の低下あるいは無効な消毒
剂が見出された場合，より有効な消毒剤へと切り替え， あるいは消毒剤使用法の改良などをしていくことが，院 内感染を防止する上で極めて有用な手段となるのではな いかと考光, 今後も定期的な検討を加えていくつもりで ある・

謝辟 本研究に際し,で協力をいただいた山形大学医 学部付属病院中央検查部の高橋長一郎先生に感謝しま す.また, 本研究の一部は昭和61年度文部省科学研究費 補助金により行った。ととに記して感謝します。

\section{引用 文 献}

1）木村龍太郎 : 最新医学, 36, 1788 (1981).

2) P.J. Geiseler, B. Harris, and B.R. Andersen: J. Clin. Microbiol., 15, 728 (1982).

3) E.M. Cryan, F.R. Falkiner, T.E. Mulvihill, C.T. Keaned and P.W.N. Keeling: J. Hosp. Infect., 5, 371 (1984).

4) L.S. Young: Am. J. Med., 70, 398 (1981).

5) 林泉, 岡本宏明, 大泉耕太郎, 佐々木昌子, 渡 辺 彰, 青沼清一, 大沼菊夫, 今野 淳, 川名林 治 : 感染症学誌, 56, 101 (1982).

6) 石山俊次 : 臨床医, 1，576 (1975).

7）奥田 清, 島岡正幸：現代の层療，18，1205 (1976).

8）安生紗枝子, 加賀美操, 佐 藤たか子, 大倉真知 子, 近藤芳子, 石坂哲夫, 金子康子, 小川正俊, 五島瑳智子：病院薬学, 2, 280 (1977).

9）五島瑳智子, 金子康子, 川崎賢二, 安生紗枝子, 加賀美操, 佐藤たか子, 大倉真知子, 三好由紀 子, 宮下 敏: 臨床病理, 25, 684 (1977).

10）富岡一, 小林芳夫, 内田 博, 萩原 薫 : 臨床 と細菌, 5, 29 (1978).

11）辻 明良, 関口金雄, 金子康子, 川崎賢二, 小川 正俊, 五島瑳智子: 感染症学誌, 53, 292 (1979).

12）川上由行, 宮本秀雄, 金井正光, 早松京子 : 臨床 と細菌, 10, 427 (1983).

13）森下憲一, 楖原雅代, 竹内美恵子, 原久美子, 䈷 生泰子, 杉江紀信, 重田勝美, 大橋昭任, 梲原文 孝: 医楽ジャーナル, 20, 97 (1984).

14）城野久美子, 上村都美子, 久野光造, 東出栄治 : 薬誌, 105, 751 (1985).

15）吉村正一郎, 日比元い子, 大野裕子：化学㙩法の 領域, 3, 904 (1987).

16）白石 正, 仲川義人, 高橋長一郎, 北目文郎 : 日 本細菌学雑誌, 41,812 (1986).

17）中野愛子：臨床と細菌, 5, 220 (1978).

18）坂 義人：日泌誌, 64,829 (1973).

19）富岡 一：日本細菌学雑誌, 34, 521 (1979). 